\title{
Constitutionally Regulating Telephone Harassment: An Exercise in Statutory Precision
}

\author{
M. Sean Royall $\dagger$
}

\section{INTRODUCTION}

For many years our society has benefited from the telephone as an inexpensive means of instantaneous communication. It provides convenient and virtually unlimited access to people wherever they may work or reside, but this capability can also make the telephone an "instrument for inflicting incalculable fear, abuse, annoyance, hardship, disgust, and grief on innocent victims."

Most states and the federal government have enacted statutes that criminalize forms of telephone harassment. ${ }^{2}$ Yet the offense is not one which lends itself to precise statutory definition. At least not without either incidentally prohibiting expression that is protected by the First Amendment (the problem of "overbreadth") or defining the prohibited conduct so imprecisely as to violate the Fourteenth Amendment's ban on vague laws (the problem of "vagueness"). ${ }^{3}$ The majority of telephone harassment statutes have been challenged on one or both of these bases, and many statutes have been invalidated. From the legislators' point of view matters have only been made worse by the courts which have reviewed these statutes, relying as they have on highly procedural holdings and offering little in the way of substantive guidance.

$\dagger$ B.S., Texas A \& M University, 1986; J.D. Candidate 1990, The University of Chicago.

1 HR Rep No 1109, 90th Cong, 2d Sess 2 (1968), in 1968 USCCAN 1915, 1916.

${ }^{2}$ See, for example, the Connecticut telephone harassment statute, Conn Gen Stat Ann $\S 53 a-183(a)(3)$ (West 1985)(upheld in Gormley v Director, Connecticut State Dept. of Probation, 632 F2d 938, 940 (2d Cir 1980)). See also the federal telephone harassment statute, 47 USC § 223(a)(1)(1982 \& Supp 1986)(upheld in United States v Lampley, 573 F2d 783, 786-87 (3d Cir 1978)). For a condensed summary of the various state statutes regulating telephone harassment, see Comment, A Remedial Approach to Harassment, 70 Va L Rev 507, 535-44 (1984).

${ }^{3}$ For an overview of how the overbreadth and vagueness doctrines have been applied to telephone harassment statutes, see Annotation, Validity, Construction, and Application of State Criminal Statutes Forbidding Use of Telephone to Annoy or Harass, 95 ALR3d 411 (1979); Annotation, Prohibition of Obscene or Harassing Telephone Calls in Interstate or Foreign Communications Under 47 USCS $\S 223,50$ ALR Fed 541 (1980). 
This Comment explores the constitutional issues that legislators confront when they attempt to proscribe harassing non-commercial telephone calls ${ }^{4}$ and seeks to guide the difficult legislative task of regulating harassing telephone calls in a way consistent with the First and Fourteenth Amendments. Section I reviews the overbreadth and vagueness doctrines and shows that the courts' flawed application of the doctrines to telephone harassment statutes has created nothing but uncertainty. Overbreadth and vagueness focus on procedure-not substance. These doctrines do not define what types of substantive expression the government may restrict, but rather, monitor how the government may go about the business of regulating without violating the substantively defined boundaries of protected speech. In reviewing telephone harassment statutes, however, the courts have tried to determine whether such statutes reach beyond the bounds of legitimate regulation into the realm of protected expression without first determining what types of telephonic expression are indeed protected. They have invalidated statutes in order to protect the substance of the First Amendment without first determining what, in the context of telephone communication, that substance is.

After exploring the judiciary's flawed application of the overbreadth and vagueness doctrines, section II answers the primary, albeit neglected, question: To what extent may the state, consistent with the First and Fourteenth Amendments, regulate expression in the context of harassing telephone calls? ${ }^{5}$ This Comment argues that the State's authority to regulate harassing calls derives from the need to protect unwilling recipients from offensive intrusions of privacy. Thus the State's regulatory authority should extend only to cases where a caller invades, in an "essentially intolerable manner," the "substantial privacy interests" of the recipient.

Finally, section III proposes a model statute based on the standards and guidelines developed in section II. Among the unique features of the statute are its treatment of speech restric-

- Commercial telephone harassment raises distinct constitutional issues. See Note, Give Me a Home Where No Salesmen Phone: Telephone Solicitation and the First Amendment, 7 Hastings Const L Q 129, 136-38 (1979).

s The Supreme Court has not yet answered this question. In fact, it has denied certiorari to two cases posing this problem: Gormley v Director, Connecticut State Dept. of Probation, 632 F2d 938 (2d Cir 1980), cert denied, 449 US 1023 (1980); and Thorne $v$ Bailey, 846 F2d 241 (4th Cir 1988), cert denied, 109 S Ct 538 (1988). In dissenting from the denial of certiorari in Gormley, Justice White noted the wide disagreement among state courts concerning the proper application of First Amendment principles in the area. Gormley, 449 US at 1025 . 
tions in the context of intimate relationships, and its provision for a self-executing notice remedy for recipients of harassing calls.

\section{Overbreadth and Vagueness as Applited by the Courts}

A legislator preparing to draft a law regulating expression naturally looks to the courts for guidance, seeking to avoid categories of speech already determined by the courts to be constitutionallyprotected. He knows that a law capable of intruding on one of those categories may be held overbroad. Yet in the telephonic expression context, no court has defined the parameters of such a category; consequently, the legislator does not know the limits placed on his proscriptive powers by the First Amendment. $\mathrm{He}$ must beware of crossing a border whose existence the courts have posited, but whose location they have not yet identified. Instead, the legislator will find only numerous and conflicting decisions striking down various statutes because their terms were deemed vague or overbroad.

This Comment seeks to provide the substantive direction that is currently lacking for this category of speech. Before doing so, the Comment reviews the underpinnings of the overbreadth and vagueness doctrines and examines three factors that are particularly salient to the constitutional issues posed by telephone harassment legislation: the statutory requirement of specific intent, the distinction between conduct and speech, and the treatment of vagueness inherent in certain statutory terminology.

\section{A. Overbreadth and Vagueness Doctrines}

1. Overbreadth.

A criminal statute is overbroad if it forbids not only behavior properly subject to proscription but conduct protected by the First Amendment as well. Overbroad laws pose two basic threats: they may punish innocent persons for exercising their constitutional right of free expression, and they may inhibit others from exercising that right (the so-called "chilling effect"). ${ }^{6}$

The overbreadth doctrine aims to achieve regulatory precision, requiring that "the means chosen by the legislature must be no broader than necessary to achieve legitimate governmental purposes." In this sense the doctrine focuses on procedure, not sub-

- Spears v State, $337 \mathrm{~S} 2 \mathrm{~d} 977,980$ (Fla 1976). See Note, The Chilling Effect in Constitutional Law, 69 Colum L Rev 808 (1969).

" Henry Paul Monaghan, Overbreadth, 1981 S Ct Rev 1, 3. 
stance. When a court declares unconstitutional a state law prohibiting political demonstrations on public property, it places an entire category of expression beyond the pale of government restriction. By contrast, when a court invalidates a statute because a particular term is overbroad, it merely ensures that a category of speech previously defined as protected is not imperiled by the imprecision of the statute. The overbreadth doctrine patrols the parameters of constitutionally-protected speech.

In the absence of an authoritative judicial construction limiting an otherwise overbroad statute to constitutional applications, ${ }^{8}$ a court may find the statute invalid on its face and in need of redrafting to excise the constitutional flaw. ${ }^{9}$ Because of the potentially unlimited scope of the overbreadth doctrine, however, many courts refrain from strict application of the rule, refusing to invalidate a statute unless it is shown to be "substantially overbroad."10 The Supreme Court has endorsed this restraint for the category of cases in which a statute proscribes a mixture of speech and conduct. $^{11}$

\section{Vagueness.}

The vagueness doctrine declares a law unconstitutional if persons "of common intelligence must necessarily guess at its meaning and differ as to its application."12 The doctrine reflects two Fourteenth Amendment due process concerns: first, that "no one ... be required at peril of life, liberty or property to speculate as to the

B "A statute which is facially overbroad may be authoritatively construed and restricted to cover only conduct which is not constitutionally protected and, as so construed, the statute will thereafter be immune from attack on grounds of overbreadth." State $v$ Thompson, 237 Kan 562, 701 P2d 694, 697 (1985).

- A court may also find a facially valid statute unconstitutional "as applied" to an individual litigant.

10 "Substantial overbreadth" seems to require a showing of actual or serious potential encroachments on fundamental rights. The Supreme Court has defined the standard in this way:

[T] $T$ he mere fact that one can conceive of some impermissible applications of a statute is not sufficient to render it susceptible to an overbreadth challenge. ... There must be a realistic danger that the statute itself will significantly compromise recognized First Amendment protections of parties not before the Court for it to be facially challenged on overbreadth grounds. Members of City Council of Los Angeles $v$ Taxpayers for Vincent, 466 US 789, 800-01 (1984).

11 " $[P]$ articularly where conduct and not merely speech is involved, we believe that the overbreadth of a statute must not only be real, but substantial as well, judged in relation to the statute's plainly legitimate sweep." Broadrick v Oklahoma, 413 US 601, 615 (1973).

${ }^{12}$ Connally $v$ General Construction Co., 269 US 385, 391 (1926). 
meaning of penal statutes"; ${ }^{13}$ and second, that laws establish objective standards to guide executive and judicial authorities in administering justice. ${ }^{14} \mathrm{~A}$ concern for the uninhibited exercise of expressive rights protected by the First Amendment also underlies the vagueness doctrine. ${ }^{16}$ The Supreme Court has intimated, for instance, that "stricter standards of permissible statutory vagueness may be applied to a statute having a potentially inhibiting effect on speech; a man may the less be required to act at his peril here, because the free dissemination of ideas may be the loser."16

\section{B. Specific Intent}

Virtually all courts upholding telephone harassment statutes mandate that the statutes require a caller to possess a specific, culpable intent.17 A specific intent requirement mitigates overbreadth concerns because it narrows the scope of criminal proscriptions. ${ }^{18}$

${ }^{13}$ Lanzetta $v$ New Jersey, 306 US 451, 453 (1939).

14 Grayned v City of Rockford, 408 US 104, 108-09 (1972) ("A vague law impermissibly delegates basic policy matters to policemen, judges, and juries for resolution on an ad hoc and subjective basis, with the attendant dangers of arbitrary and discriminatory application."). See also Papachristou v City of Jacksonville, 405 US 156, 168 (1972).

is See Grayned, 408 US at 109 ("Uncertain meanings inevitably lead citizens to 'steer far wider of the unlawful zone. .. ." ")(citations omitted); see also Anthony G. Amsterdam, The Void-for-Vagueness Doctrine in the Supreme Court, 109 U Pa L Rev 67, 76 (1960).

${ }^{16}$ Smith v California, 361 US 147, 151 (1959). See also Note, Vagueness Doctrine in the Federal Courts: A Focus on the Military, Prison and Campus Contexts, 26 Stan L Rev $855,869-70$ (1974).

17 Some statutes, however, do not require intent for telephone calls containing obscene, lewd, or profane language because such forms of expression "are no essential part of any exposition of ideas." Chaplinsky v New Hampshire, 315 US 568, 572 (1942). See, for example, subsection (A) of the federal statute, 47 USC $\$ 223(\mathrm{a})(1)$ (cited in note 2 and excerpted in note 100 ).

${ }^{18}$ Legislatures and courts have employed methods in addition to a specific intent requirement to clarify the scope of telephone harassment statutes. See State $v$ Elder, 382 S2d 687, 691-93 (Fla 1980)(call must be unwanted, unsolicited or nonconsensual); City of Everett $v$ Moore, 37 Wash App 862, 683 P2d 617, 619 (1984) (holding statute unconstitutionally vague, but implying result would differ if statute required recipient to take call in a place which recipient reasonably expects to be private). For example, although anonymous calls may contain entirely legitimate speech, they have been found to "militat[e] against any legitimate free speech communicative function," Elder, 382 S2d at 691 , because anonymity is "a circumstance raising discomfort and fear in the receiver of the call." Id (quoting United States v Darsey, 342 F Supp 311, 313 (E D Pa 1972)). See Jones v Municipality of Anchorage, 754 P2d 275, 279 (Alaska App 1988)(anonymous calls deemed "essentially noncommunicative"). Finally, some statutes prohibit only repetitive calls. See, for example, State v Camp, 59 NC App 38, 295 SE2d 766, 768 (1982); Caldwell v State, 26 Md App 94, 337 A2d 476, 481 (1975); Constantino v State, 243 Ga 595, 255 SE2d 710, 713 (1979).

Courts sometimes invalidate statutes that do not require specific, culpable intent, holding that such statutes impermissibly regulate speech. See generally Walker v Dillard, 523 F2d 3, 5 (4th Cir 1975); Radford v Webb, 446 F Supp 608, 610-11 (W D NC 1978). And some courts view intent requirements as ensuring that telephone harassment statutes do not in- 
Likewise, it overcomes statutory vagueness because it clarifies the nature of prohibited conduct. But contrary to the view of some courts, a specific intent requirement will not immunize telephone harassment statutes from all constitutional infirmities.

\section{The narrowing and clarifying effect of intent.}

A specific intent requirement narrows the scope of telephone harassment statutes because it requires the caller to intend to cause the recipient actual psychic or emotional harm. Most telephone harassment statutes couple the intent requirement with an "effect" requirement; that is, the caller must intend to "annoy," "harass," or "alarm" the recipient. ${ }^{19}$ As some courts have noted, ${ }^{20}$ however, in both overbreadth and vagueness cases the utility of requiring intent depends on the definiteness of the intended "effect." A statute requiring "intent to annoy," for instance, is arguably no more definite than a statute with no intent requirement, because the term "annoy" lacks clarity. Thus, in Gormley v Director, Connecticut State Dept. of Probation, ${ }^{21}$ a decision upholding the Connecticut telephone harassment statute, ${ }^{22}$ Judge Mansfield argued that even though the statute in question required a specific "intent to annoy," it would still be overbroad since it "prohibit[s] any telephone call made 'with intent to annoy' which had such effect." ${ }^{23}$ As Judge Mansfield pointed out, people may make intentionally "annoying" telephone calls for "legitimate," "constitutionally-protected" purposes: for example, to harangue their Congressman, collect payment of a past due bill, or complain about the quality of goods or services. ${ }^{24}$ Thus, the specific intent requirement fails to eliminate overbreadth concerns whenever the "effect" (e.g., to har-

fringe on constitutionally-protected expression. See State v Hagen, 27 Ariz App 722, 558 P2d 750, 753 (1976); Kinney v State, 404 NE2d 49, 51 (Ind App 1980); Bachowski $v$ Salamone, 139 Wis 2d 397, 407 NW2d 533, 537-38; Thorne v Bailey, 846 F2d 241, 243-44 (4th $\mathrm{Cir}$ 1988). But this view is by no means unanimous. See, for example, State $v$ Anonymous, 34 Conn Supp 689, 389 A2d 1270, 1273 (1978) (addition of intent requirement in no significant way alleviates the inhibiting effect on freedom of expression).

19 The terms chosen to define the required "effect" have a significant bearing on the overbreadth analysis. See, for example, State v Dronso, 90 Wis $2 d 110,279$ NW2d 710, 713 14 (Wis App 1979).

${ }^{20}$ See State v Blair, 287 Or 519, 601 P2d 766, 768 (1979) (en banc).

${ }^{21} 632$ F2d 938, 942 (2d Cir 1980).

${ }^{22}$ Conn Gen Stat Ann § 53a-183(a)(3) (cited in note 2).

${ }^{23} 632$ F2d at 944 (Mansfield concurring) (emphasis added). Judge Mansfield also reasoned that the argument that "protected" speech is speech with a "Iegitimate purpose" is circular and renders the analysis incomplete because it fails to define what types of telephonic expressions are protected by the First Amendment.

24 Id. See also People v Klick, 66 Ill 2d 269, 362 NE2d 329, 331-32 (Ill 1977). 
ass, to annoy, to alarm, etc.) associated with the intent provision is broad enough to encompass a substantial amount of protected activity. ${ }^{25}$

A specific intent requirement may, however, clarify statutory language and thereby mitigate vagueness concerns. ${ }^{26}$ The underlying premise is "that a person already bent on serious wrongdoing has less need for notice and that a citizen who refrains from acting with morally bad intent is not endangered by the statutory sanction." ${ }^{27}$ Additionally, some courts find that a specific intent requirement furnishes a more justiciable standard, since the lawfulness or unlawfulness of the act no longer turns on the potentially unpredictable, subjective reactions of the recipient, but on the specific intent of the caller. ${ }^{28}$

\section{The problem of ambiguous intent.}

Even if the courts could dispel the ambiguity of the effects sought to be prohibited by telephone harassment regulation, they would still have to contend with the ambiguity of intent itself. Relying on a specific intent requirement to constitutionally clarify and narrow telephone harassment statutes presumes that a caller's intent is constant and easily ascertained. Often, however, this is not true. For instance, a caller may initiate a call with a legitimate communicative purpose but at some point during the conversation become angry and abusive. ${ }^{29}$ In the absence of aggravating factors, ${ }^{30}$ convicting such callers would run afoul of the First and

${ }^{25}$ At times decisions in the area have turned on semantic quibbles over, for instance, the difference in meaning between "harass" and "annoy." Interestingly, Webster's Dictionary defines "annoy" as "to harass, esp[ecially] by quick and brief attacks." Webster's Third World Dictionary (unabridged) 87 (Merriam-Webster, 1986). Meanwhile, the same source defines "harass" as "to vex, trouble, or annoy continually or chronically." Id at 1031.

${ }^{26}$ See, for example, State v Gattis, 105 NM 194, 730 P2d 497, 503 (NM App 1986); Caldwell, 337 A2d at 483.

${ }_{27}$ Note, Due Process Requirements of Definiteness in Statutes, 62 Harv L Rev 77, 85 (1948), quoted in Caldwell, 337 A2d at 482. The Supreme Court gave credence to this view in Screws $v$ United States, 325 US 91, 101-02 (1945):

The constitutional vice in [a vague] statute is the essential injustice to the accused of placing him on trial for an offense, the nature of which the statute does not define and hence of which it gives no warning. [Citations omitted.] But where the punishment imposed is only for an act knowingly done with the purpose of doing that which the statute prohibits, the accused cannot be said to suffer from lack of warning or knowledge that the act which he does is a violation of law.

${ }^{28}$ See State $v$ Larsen, 37 Or App 425, 588 P2d 41, 43 (1978). And see Coates v City of Cincinnati, 402 US 611, 614 (1971); Constantino, 255 SE2d at 713.

${ }^{20}$ See State $v$ Thorne, 333 SE2d 817, 821 (W Va 1985) (Miller dissenting).

30 Aggravating circumstances might include such characteristics as anonymity, repetition, or the use of obscene language. 
Fourteenth Amendments by "chilling" protected communications, since some callers would think twice before initiating calls that might escalate into a heated exchange.

Some courts and legislatures address this concern by specifying that the caller must exhibit the "sole intent" to harass;" others restrict the scope of the statute less by requiring "initial intent" - "when the telephone call was made ... the caller's intent [must have been] to annoy, abuse, threaten, or harass."32 Where intentionally harassing anonymous calls are concerned, however, there is no fear of chilling protected speech, and thus no need to require a "sole," or "initial," intent provision. ${ }^{33}$

\section{The Conduct-Speech Distinction}

The Supreme Court has held that conduct containing expression may in some instances be restricted without violating the First Amendment. ${ }^{34}$ In addition, the Court has said that the function of the overbreadth doctrine "attenuates as the otherwise unprotected behavior it forbids the State to sanction moves from 'pure speech' toward conduct."3s Thus, where a statute regulates conduct containing expression, courts may give less weight to the statute's "chilling" effect. ${ }^{36}$

${ }^{31}$ See State v Brown, 274 SC 506, 266 SE2d 64, 65 (1980). See also Jones v Municipality of Anchorage, 754 P2d 275, 279 (Alaska App 1988). It may be that "sole intent" is constitutionally required. In subsection (D) of the federal telephone harassment statute, 47 USC $\S 223(a)(1)$ (cited in note 2), Congress required the sole intent to harass in "repeated telephone calls, during which conversation ensues," but where no other aggravating factors exist. Though subsections (A), (B), and (C) of the same statute do not contain the "sole intent" requirement, subsections (A) and (B) apply to specific situations in which constitutional protections are generally considered to be at a minimum (i.e., obscene calls and intentionally threatening or harassing anonymous calls). And subsection (C) does not apply to speech at all but to "caus[ing] the telephone of another repeatedly or continuously to ring, with intent to harass ...." Congress apparently intended that, absent aggravating factors, the statute require a caller to have the exclusive purpose of harassing the recipient.

${ }^{32}$ Elder, 382 S2d at 691 (emphasis added). See also Thorne, 333 SE2d at 824 (Miller dissenting).

${ }^{33}$ See note 85 .

34 "[I]t has never been deemed an abridgment of freedom of speech or press to make a course of conduct illegal merely because the conduct was in part initiated, evidenced, or carried out by means of language, either spoken, written, or printed." Cox $v$ Louisiana, 379 US 536, 563 (1965)(citation omitted).

${ }^{33}$ Broadrick v Oklahoma, 413 US 601, 615 (1973).

${ }^{36}$ Some courts have suggested that the conduct-speech distinction is irrelevant to the due process concerns of the vagueness doctrine. People v Norman, 703 P2d 1261, 1267 (Colo 1985) (en banc). Others, however, have held that to the extent that a statute regulates conduct rather than speech, otherwise vague formulations may be permissible. See Hiett $v$ United States, 415 F2d 664, 672 (5th Cir 1969). See also Note, Vagueness Doctrine in the Federal Courts, 26 Stan L Rev 855, $860 \mathrm{n} 27$ (1974) ("The more directly a statute is aimed 
Several courts have seized upon the conduct-speech distinction as a means of upholding telephone harassment statutes. ${ }^{37}$ For instance, the Fourth Circuit recently relied on the conduct-speech distinction to affirm a West Virginia Supreme Court decision upholding that state's telephone harassment statute against an overbreadth challenge. ${ }^{38}$ According to the pluralities in both courts, "[p]rohibiting harassment is not prohibiting speech, because harassment is not protected speech. Harassment is not communication, although it may take the form of speech."39

This sort of judicial side-stepping is troubling. The courts may be correct that harassing phone calls are not constitutionally-protected speech. But such a holding should not be reached by judicial fiat. As Chief Justice Miller said in his dissent in State $v$ Thorne, the cases upholding statutes on the basis that phone calls are conduct "have a sophistry that [is] repugnant where, as here, legitimate conversation ensues." ${ }^{\prime 40}$ To declare that a statute forbids only conduct might be acceptable if conversation were not an element of the offense. But where, as in Thorne, conversation is required by the statute, the First Amendment cannot be ignored.41 In statutes focusing on actual verbal communication, conduct and speech are not completely separable unless the category of perverse conduct proscribed by the statute expressly excludes all forms of protected communication.

\section{Vague Terminology}

Given the nature of the regulated activity and the range of

at regulating first amendment related activity, the stricter the scrutiny should be.").

${ }^{37}$ See Gormley, 632 F2d at 941-42; Baker $v$ State, 16 Ariz App 463, 494 P2d 68, 70 (1972)("[The statute] is not directed at the communication of thoughts or ideas but at conduct, in other words, the use of the telephone to terrify, intimidate, threaten, harass, annoy or offend people by use of the language proscribed."); Elder, 382 S2d at 690 . See also Gattis, 730 P2d at 502; People v Taravella, 133 Mich App 515, 350 NW2d 780, 783 (1984); Camp, 295 SE2d at 768; State v Jaeger, 249 NW2d 688, 691-92 (Iowa 1977); Donley $v$ City of Mountain Brook, 429 S2d 603, 607-08 (Ala Cr App 1982), rev'd on other grounds, Ex parte Donley, 429 S2d 618 (Ala 1983); State v Crelly, 313 NW2d 455, 457 (SD 1981).

${ }^{38}$ Thorne $v$ Bailey, 846 F2d 241, 243-44 (4th Cir 1988)(affirming State $v$ Thorne, 333 SE2d 817 (W Va 1985)).

39 Thorne $v$ Bailey, $846 \mathrm{~F} 2 \mathrm{~d}$ at 243 (quoting State v Thorne, $333 \mathrm{SE} 2 \mathrm{~d}$ at 819 ).

10 State $v$ Thorne, $333 \mathrm{SE2d}$ at 824 (Miller dissenting).

12 Thorne was convicted of violating W Va Code $\$ 61-8-16(a)(4)$ (1984), which makes conversation an element of the offense. See State v Thorne, 333 SE2d at 824 (Miller dissenting). See also Gormley, 632 F2d at 944 (Mansfield concurring) ("Labelling the statute as one prohibiting 'conduct' does [nothing to] resolve th[e] constructional dilemma [because i]n most cases the 'conduct' punished is the oral communication rather than the ringing of the telephone bell."). 
behavior restricted, it is difficult to draft telephone harassment statutes precisely. Furthermore, the courts have supplied no explanatory principle to aid legislators in drafting future statutes. Indeed, the challenge of drafting a precise statute has only been complicated by the fact that the same terms have been found vague by some courts and sufficiently precise by others. The words and phrases which are most often challenged as vague may be separated into two general categories: those that describe the offense in terms of the caller's intended effect on the recipient (e.g., "harass," "alarm," and "intimidate"), and those that describe the offensive content of the calls (e.g., "obscene," "profane," "vulgar," and "indecent").

\section{Terms describing effect on the recipient.}

Virtually every term used to define the caller's intended effect has been challenged as unconstitutionally vague. ${ }^{42}$ While in most instances the statutes have been upheld, this is due largely to the clarifying effects of other statutory elements or to the willingness of courts to impose authoritative constructions of those terms; ${ }^{43}$ the statutes' survival can hardly be attributed to the precision of the terms themselves.

The courts disagree over the clarity of certain terms. For instance, they define the terms "annoy" and "alarm" in a variety of ways. Likewise, while some courts find the common phrase "annoys or seriously alarms" unconstitutionally vague, others hold it to be neither vague nor overbroad. ${ }^{44}$ As with overbreadth, no one principle explains the distinctions courts draw in applying the vagueness doctrine. They simply announce that certain words-for example, "harass"-are sufficiently clear, while other terms-for

42 Compare, for example, State v Sanderson, 33 Or App 173, 575 P2d 1025, 1027 (1978), City of Everett $v$ Moore, 37 Wash App 862, 683 P2d 617, 619 (1984), and Norman, 703 P2d at 1266 (virtually identical statutes containing the phrase "alarms or seriously annoys" were found void for vagueness); with Kinney v State, 404 NE2d 49, 51 (Ind App 1980) and Donley, $429 \mathrm{~S} 2 \mathrm{~d}$ at 611 (upholding two nearly identical statutes because they particularized the offense to include only telephone calls). See also People $v$ McBurney, 750 P2d 916, 918 (Colo 1988) (en banc) (upholding use of the terms "alarm" and "annoy").

${ }^{43}$ Courts often avoid applying the vagueness doctrine by narrowing the statute through judicial construction. For instance, in upholding statutes several courts have applied "noscitur a sociis" (figuratively, "birds of a feather") - a rule of construction which provides that "general and specific words, capable of analogous meaning, when associated together, take color from each other, so that general words are restricted to a sense analogous to less general." State v Hertzog, $241 \mathrm{La} 783,131$ S2d 788, 789 (1961). See also State v Meunier, 354 S2d 535, 537-38 (La 1978); People v Parkins, 77 Ill 2d 253, 396 NE2d 22, 24 (1979).

4 See cases cited in note 42. 
example, "annoy" or "alarm"-lack precision. Telephone harassment statutes by necessity contain some vague and broad terminology, but it is senseless for courts to employ formal distinctions between such inherently imprecise terms as a way of delimiting constitutional protections. Instead, courts (and preferably, in the first instance, legislatures) must clearly define the statutory terminology.

\section{Terms describing offensive content.}

Words describing the offensive content of harassing calls-adjectives such as "profane," "lewd," "lascivious," "vulgar," "coarse," and "offensive"- are also undeniably vague. Nonetheless, courts at times uphold the use of these terms by relying on narrowing judicial constructions or on the clarifying effects of other statutory elements. ${ }^{45}$

Because of its peculiar legal meaning, the term "obscene" poses interesting vagueness problems when used in telephone harassment statutes. In Baker $v$ State, the court rejected a challenge to the Arizona statute based in part on the indefiniteness of the word "obscene." ${ }^{46}$ The Baker court made clear at the outset that the statute was not an obscenity statute, and that it would be "inane" to apply constitutional standards of obscenity to determine whether an obscene telephone call appeals to "prurient interests" or whether such activity has any redeeming social value. ${ }^{77}$ Thus, the court reasoned that the publication or display of "obscenity" and the use of "obscene" language in the course of a harassing telephone call are distinct legal issues. ${ }^{48}$

The Baker court's point is an important one. The law of obscenity punishes people for the very content of their offensive expressions. Telephone harassment statutes, on the other hand, punish intentional invasions of individual privacy. In telephone

15 See Baker, 494 P2d at 70-71 (upholding "obscene" and "profane"); Hertzog, 131 S2d at 790 (upholding "vulgar"); State v Koetting, 616 SW2d 822, 826 (Mo 1981) (en banc) (upholding the phrase "coarse language offensive to one of average sensibility").

464 P2d at 70-71.

47 Id.

48 Id. Other authorities also make this distinction. See Jaeger, 249 NW2d at 691 (upholding the phrase "obscene, lewd or profane"); Crelly, 313 NW2d at 456 (upholding the terms "obscene" and "lewd"). See also People v Weeks, 197 Colo 175, 591 P2d 91, 95 (1979) (en banc). At least one statute has been invalidated precisely because it attempted to combine the two issues. See State v Ray, 302 Or 595, 733 P2d 28, 31 (1987) (holding vague a statute that prohibited a person from subjecting "another to alarm or annoyance by telephonic use of obscenities.") 
harassment, the use of obscene language is merely a factor aggravating an independently proscribable offense. ${ }^{49}$

\section{Defining the Substantive Limits}

The preceding section illustrates the often arbitrary manner in which courts employ the overbreadth and vagueness doctrines to police governmental regulation of harassing phone calls. The two doctrines generally are useful means of guarding constitutional boundaries. One cannot methodically protect the parameters of a right, however, without first defining the extent and nature of the right and, by implication, its boundaries. But in the context of telephone harassment statutes, courts attempt just that: they apply the vagueness and overbreadth doctrines without first engaging in a substantive analysis of the parameters of "protected" speech. This section answers the question that the courts have neglected by defining the substantive limits which the First and Fourteenth Amendments impose on the statutory restriction of harassing telephone calls.

\section{A. Placing Telephone Harassment in the Field of Free Expression}

The regulation of telephone harassment, unlike other First Amendment issues, evades a narrow classification. Anonymous, obscene, speechless, and threatening calls each present unique First Amendment concerns. Only two characteristics are common to all harassing calls: they are telephone calls, most often to residences, and they are unwanted by or offensive to the recipient. Given these characteristics, how can one defend the position taken by many courts that "the Constitution will tolerate greater limits on the dialogue of a speaker" in the context of harassing telephone calls than it will tolerate in other categories of expression? ${ }^{50}$ This section will illustrate that the privacy interest of the unwilling recipient most effectively distinguishes telephone harassment from speech in other contexts.

The Supreme Court has shown "no lack of solicitude for the right of an individual 'to be let alone' in the privacy of the home." Indeed, the Court has viewed "protecting the well-being,

48 This distinction has important implications for vagueness analysis. See text at notes 82-83.

so State $v$ Keaton, 371 S2d 86, 93 (Fla 1979) (emphasis added).

s1 Carey v Brown, 447 US 455, 471 (1980). 
tranquility, and privacy of the home ... [as a state interest] of the highest order in a free and civilized society."62 While the law presumes that each person bears the risk of encountering a certain amount of objectionable expression in the public domain, ${ }^{\mathrm{53}}$ the home is a sanctuary. ${ }^{54}$ As the Supreme Court has stated, "There simply is no right to force speech into the home of an unwilling listener."'ss

Unwanted intrusions into the privacy of the home are the most basic form of trespass. Before the telephone, intrusions on a citizen's residential privacy were essentially physical invasions of property. The telephone decouples privacy and property, making invasions of privacy possible without physical invasion of property ${ }^{56}$ Moreover, property lines have traditionally been respected because of two potential costs associated with trespass: forcible resistance and legal liability. By nullifying forcible resistance as an obstacle to privacy invasions, the telephone eliminates one of the two deterrents to trespasses. Because many telephonic trespasses are anonymous, one can prevent the intrusion on one's privacy only by screening calls, delisting one's telephone number, or simply not answering the phone. Thus, only the second of the two conventional bars on privacy intrusions remains: legal liability.

Like the telephone, radio and television are also media through which expression is conveyed into the privacy of the home. The Supreme Court has recognized limits on expression delivered via the public airwaves because of the privacy interests involved. In FCC $v$ Pacifica Foundation, the Supreme Court found that the "uniquely pervasive" nature of the broadcast media permitted restrictions on expression that would be unconstitutional in other, more public contexts: "[I]n the privacy of the home ... the individual's right to be left alone plainly outweighs the First Amend-

32 Id.

${ }^{33}$ See Cohen v California, 403 US 15, 21 (1971); Erznoznik v Jacksonville, 422 US 205, 209-10 (1975).

s4 As the Supreme Court recently explained, "[a] special benefit of the privacy all citizens enjoy within their own walls, which the State may legislate to protect, is an ability to avoid intrusions." Frisby v Schultz, 108 S Ct 2495, 2502 (1988).

ss Id at 2502. See also Rowan v United States Post Office Dept., 397 US 728, 737 (1970); FCC v Pacifica Foundation, 438 US 726, 748 (1978); Kovacs v Cooper, 336 US 77, 86-87 (1949).

so Interestingly, intrusions by telephone were the catalyst for the Supreme Court's abandonment of physical, property-based limits on trespass by the government in Fourth Amendment search and seizure cases. See Katz $v$ United States, 389 US 347, 350-53 (1967)(the Court shifted the inquiry from whether property lines were actually penetrated by the search to whether reasonable expectations of privacy were violated). 
ment rights of an intruder." ${ }^{\prime 67}$ According to the Pacifica Court, " $[t]$ o say that one may avoid further offense by turning off the radio when he hears indecent language is like saying that the remedy for an assault is to run away after the first blow." noted the analogy to harassing telephone calls: "One may hang up on an indecent phone call, but that option does not give the caller a constitutional immunity or avoid a harm that has already taken place."59 Just as the listener or viewer usually has no notice of what he will encounter when he tunes into a radio or television broadcast, the recipient of a telephone call seldom knows what will confront him when he picks up the receiver.

A person's inability to avoid offensive communicative intrusions is an important concern in First Amendment doctrine. When the audience is a "captive" one, the First Amendment allows the State to "recognize degrees of evil and adapt its legislation accordingly." "60 In Frisby $v$ Schultz, the Supreme Court upheld a residential anti-picketing ordinance in part because "resident[s were] figuratively, and perhaps literally, trapped within the[ir] home[s], and ... left with no ready means of avoiding the unwanted speech."61 Likewise, in Kovacs $v$ Cooper, the Court upheld an ordinance restricting the public use of sound trucks and amplifiers, finding that " $[\mathrm{t}]$ he unwilling listener ... [i]n his home . . . is practically helpless to escape this interference with his privacy."62

s7 438 US at 748 .

ss Id at $748-49$.

s9 Id at 749 .

60 Lehman v Shaker Heights, 418 US 298, 302 (1974)(plurality opinion)(quoting Packer Corp. $v$ Utah, 285 US 105, 110 (1932)).

${ }_{61} 108 \mathrm{~S}$ Ct at 2503-04.

a2 336 US 77, 86-87 (1949).

Not all expressive intrusions on residential privacy, however, have been found unprotected. For instance, in Bolger v Youngs Drug Products Corp., 463 US 60 (1983), the Supreme Court observed that recipients of objectionable mailings could avoid the intrusion by making the "short, though regular, journey from mailbox to trashcan." Id at 72 (quoting Lamont $v$ Commissioner of Motor Vehicles, 269 F Supp 880, 883 (S D NY 1967)). The question in the Court's view was not whether the recipient was "captive," but whether the burden of avoidance was an "acceptable" one. In Bolger, the Court believed it was. 463 US at $72-73$.

The intrusion on the recipient's privacy caused by offensive mailings, however, is minimal compared with the encroachment on the sanctity of the home caused by harassing telephone calls. Harassing telephone calls are intensely personal invasions. The recipient of a harassing call is not like a person in a crowd who when exposed to an offensive slogan can merely "avert his eyes" to avoid the intrusion. See Cohen, 403 US at 21 . Nor is he like the recipient of unwanted mail, whose privacy interest is violated only by the offending statements themselves. The caller's message is "directed at the person of the hearer," Cantwell $v$ Connecticut, 310 US 296, 309 (1940), who, if even for a few moments, is helpless to escape. Thus the recipient of a harassing call is confronted by the person making the statements, in 
In order to foster uninhibited public discourse, the First Amendment doctrine places the external costs of offensive expression made in most public forums on the public. The harm is diffuse and avoidable, and the speaker's freedom near absolute, since he need not self-censor his ideas to exclude offensive subject matter. When a speaker uses the telephone to impose offensive views on an unwilling recipient in his home, however, the harm is particularized, nearly unavoidable, and analogous to conduct giving rise to the common law tort of trespass; ${ }^{63}$ in such circumstances, society has an interest in imposing on the speaker some, or all, of the costs of his expression.

\section{B. The Cohen Standard}

To show that expression invasive of individual privacy may constitutionally be regulated goes only part of the way toward providing guidance for the regulation of harassing phone calls; a principle for determining when and to what extent the state may restrict such calls is still needed. Such a principle emerges in Cohen $v$ California. ${ }^{64}$

In Cohen, the Supreme Court reversed the conviction of a draft protester under a statute prohibiting willful disturbances of the peace. The protestor entered a California courthouse wearing a jacket displaying the words "Fuck the Draft." Given the uniquely public context of Cohen's distateful mode of expression, the Court rejected the argument that it was thrust upon unwilling or unsuspecting viewers who were unable to avoid exposure to the crude form of protest. ${ }^{65}$ The Court, in distinguishing the context of Cohen's speech from more private settings, stated that the "government may properly act in many situations to prohibit intrusion into the privacy of the home of unwelcome views and ideas which cannot be totally banned from the public dialogue."66 The Court then articulated the parameters of the government's authority to regulate unwelcomed offensive expression: "The ability of the gov-

addition to being unwillingly exposed to the statements themselves.

${ }^{63}$ Harassing telephone calls resemble actual trespasses more than harassing door-todoor solicitations do. A ringing telephone beckons to be answered, though the identity of the caller is seldom known in advance. As soon as the receiver is lifted off the hook, the trespass begins. The caller and his unwanted message have entered the privacy of the home. By contrast, when an unwanted solicitor comes to the door, the resident, after learning the identity of the visitor, can choose whether or not to admit him.

ot 403 US 15 (1971).

Bs Id at 21.

${ }^{8 B}$ Id. 
ernment, consonant with the Constitution, to shut off discourse solely to protect others from hearing it is . . . dependent upon a showing that substantial privacy interests are being invaded in an essentially intolerable manner." 67 This statement provides a useful standard for drafting and evaluating telephone harassment statutes.

\section{Intolerability of Communicative Invasions}

The Cohen "intolerability" standard as applied to telephone harassment statutes would require that such regulations be limited in application to intolerable intrusions of substantial privacy interests. This standard can define the basic substantive limits placed on the regulation of telephone harassment by the First Amendment. To give legislators clear guidance, courts must interpret "intolerability" objectively. The analysis would thus focus on the following question: Given the nature of the offensive calls and the nature of the privacy interests of the recipient, are the calls something society can and should endure for the cause of free expression ${ }^{68}$

The "intolerability" standard is not a precise formula. Like most constitutional tests, it merely identifies the relevant concerns bearing on the substantive analysis. Its primary value is in addressing the substantive issues of telephone harassment, and thereby giving better guidance to legislators than the current ad hoc and unprincipled jurisprudence. The intolerability standard also answers both overbreadth and vagueness questions. By employing an objective "intolerability" standard, a court can more easily interpret a statute's reach. Any statute defined in reference to such a standard will, by definition, be sufficiently clear to constitutionally guide conduct.

The most important factors bearing on the "intolerability" of a call include: (1) whether the caller had a culpable intent when he initiated the call, or whether such an intent developed during the conversation; (2) whether the caller identified himself; (3) whether the caller made repeated calls, and whether the recipient or some-

${ }^{67}$ Id (emphasis added).

68 To base the intolerability inquiry on the forbearance of a particular recipient would leave potential offenders to estimate the subjective sensitivity of the recipient. Such a requirement would be unconstitutionally vague, "not in the sense that it requires a person to conform his conduct to an imprecise but comprehensible normative standard, but rather in the sense that no standard of conduct is specified at all." Coates $v$ City of Cincinnati, 402 US 611, 614 (1971). 
one at the called number had previously instructed the caller not to call again; (4) whether actual words were spoken by the caller, and whether such words were of an obscene, lewd, or indecent nature; and (5) whether because of a preexisting relationship between the caller and the person receiving the call, the privacy interests of the recipient were not, in fact, "substantial."

\section{Substantiality of Privacy Interests}

As illustrated above, governmental protection of residential and other similar privacy interests is the primary justification for telephone harassment regulation. Even when the unwilling listener is reached in the "privacy of the home," however, this does not "automatically ... justify curtailing all speech capable of giving offense." ${ }^{\text {"6g }}$ Rather, a "substantial" privacy interest must be at stake.

When an individual receives an intentionally harassing communication in his household, this substantiality requirement would normally be met. But in some limited instances, individual privacy interests may not be so "substantial" as to warrant government intervention. Telephone harassment regulations reach far beyond the paradigm of the unknown offensive caller into the realm of communications between family members, intimates, friends, and associates. The "substantiality" of the recipient's privacy interests will vary dramatically in these situations, and consequently regulation of telephone harassment should be curtailed if a preexisting "intimate" relationship significantly reduces the privacy interests of the recipient vis-à-vis the particular caller. ${ }^{70}$

The necessity and desirability of an intimate relationship exception to telephone harassment regulation stem from two common sense observations. First, intimate relationships by definition involve voluntary relinquishment of a substantial measure of indi-

Cohen, 403 US at 21.

70 A narrow category of "intimate relationships" might presumptively include spouses, unmarried cohabitants, and intimate friends and relatives, qualified by the requirement that the caller reasonably have believed the recipient would consent both to the manner of the communication and the language used.

The category of intimate relationships arises in other areas of the law. Regarding its application to evidentiary privileges, see Developments in the Law-Privileged Communications, 98 Harv L Rev 1450, 1590 (1985). See generally Jeffrey H. Reiman, Privacy, Intimacy and Personhood, 6 Phil \& Pub Aff 26, 33-34 (1976); Kenneth L. Karst, The Freedom of Intimate Association, 89 Yale L J 624, 634 (1980). See also Mary I. Coombs, Shared Privacy and the Fourth Amendment, or the Rights of Relationships, $75 \mathrm{Cal} \mathrm{L} \mathrm{Rev} 1593$ (1987), arguing for an expanded conception of intimate relationships for the purposes of determining who may challenge searches under the Fourth Amendment. 
vidual privacy. ${ }^{71}$ Because the participants in intimate relationships depreciate the "substantiality" of their privacy interests, the government's justification for intervening to protect the recipient from unwanted intrusions is diminished as well. Second, in calls between intimate persons the culpability of the caller may be lessened, if not eliminated. People presume a greater latitude of expression with intimates than with strangers or mere acquaintances, and there will be instances in which a party has placed an otherwise offensive call on the reasonable belief that in the course of a relationship the recipient has conferred a sort of implied consent to such speech. ${ }^{72}$

Nonetheless, just as intimate relationships involve, within themselves, a relinquishment of privacy that lessens the government's interest in intervention, those same relationships, when gone sour, can become the greatest source of harassing phone calls. What is needed to protect the individual's privacy in such cases is a "notice remedy"-a statutory remedy on behalf of the recipient to instruct any harassing caller that he is not to call again, after which subsequent unsolicited calls would be forbidden. As the Supreme Court recognized in Rowan v United States Post Office Department, ${ }^{73}$ when it held that a citizen may notify the post office not to deliver offensive mail from a particular sender, an individual's privacy rights within the home are most substantial when he has expressed his desire not to receive further communications from a particular source. State enforcement of a citizen's decision to shut off communication from a particular source is not the same as state censorship of that communication. The right to notify the post office not to deliver mail from a particular sender, upheld in Rowan, and the right protected by a proposed "notice remedy" are

71 The Supreme Court has defined intimate relationships in a way consistent with this thesis. See Roberts v United States Jaycees, 468 US 609, 619-20 (1984).

${ }^{72}$ The paradigmatic case between intimates might cast the male as the caller and the female as the recipient. Thus, one might argue that this Comment favors the rights of men over women, i.e., "It is men's right to inflict [harassment] upon women in private that is protected." Catharine A. MacKinnon, Feminism Unmodified: Discourses on Life and Law 155 (Harvard, 1987) (concerning pornography). But this is simply not the case. First, the exception is not based on relational privacy but rather the voluntary relinquishment of individual privacy to another. Secondly, the intimate relationships exceptinn is limited to less aggravated forms of harassment and its effects would be moderated by the recipient's selfexecutable "notice remedy." See text at notes 73-75. So limited, the exception only gives the caller the "right" to make one harassing call. This is by no means unusual; a number of statutes have been drafted to allow a one-call "free shot." See Model Penal Code and Commentaries: Official Draft and Revised Comments $\$ 250.4$ at 361-63 (American Law Institute, 1980).

${ }^{73} 397$ US 728 (1970). 
essentially the same: that of the citizen, not the State, to choose which communications will enter the privacy of his home. ${ }^{74}$

This "notice remedy" finds support in the Supreme Court's view that citizens have an absolute right to control the information, thoughts, and ideas that enter their homes. When exercised by the individual recipient, the notice remedy would supersede the intimate relationships exception, allowing the recipient to reerect privacy barriers presumed dismantled by the exception. As was true in Rowan, the wall of privacy erected by the notice remedy would be absolute-when put on notice, "no one [would have] a right to press even 'good' ideas on an unwilling recipient." "75 However, the value of the notice remedy extends beyond the moderating effect it would have on the intimate relationships exception. The notice remedy provides all citizens with a self-executable method for avoiding repeated unwanted calls, irrespective of the nature of the call.

\section{E. The Need for Precision}

Criminal statutes restricting First Amendment liberties must be narrow and specific ${ }^{76}$ because of the potential for chilling protected expression. Nonetheless, if the Fourteenth Amendment were thought to require absolute precision, it would be impossible to legislate against telephone harassment and similar offenses. ${ }^{77}$ The basic function of the vagueness doctrine is to ensure that statutory language is sufficiently definite to give notice of what is pro-

74 Rowan is distinguishable from telephone harassment on two counts: (1) Rowan concerned arguably less intrusive communications by mail, and (2) Rowan involved traditionally less protected commercial speech. But neither of these differences weakens the inference that, as in the case of unwanted mail, a citizen should have a right to control unwanted telephone calls. If anything, these differences suggest that the citizen has a greater right to control unwanted telephone communications.

Compare Rowan with Martin v City of Struthers, 319 US 141 (1943), and Bolger, 463 US 60 (1983). In Martin, the Court invalidated a complete ban on door-to-door solicitations. The Court reasoned that while the ban would impermissibly intrude on expressive rights, the government could "make it an offense for any person to ring the bell of a householder who ha[d] appropriately indicated that he is unwilling to be disturbed." Martin, 319 US at 148. In Bolger, the Court invalidated a federal statute which prohibited the unsolicited mailing of advertisements for contraceptives. Discussing Rowan, the Bolger Court stated: "We have, of course, recognized the important interest in allowing addressees to give notice to a mailer that they wish no further mailings .... But we have never held that the Government itself can shut off the flow of mailings to protect those recipients who might potentially be offended." Bolger, 463 US at 72.

${ }^{75} 397$ US at 738.

${ }^{76}$ See NAACP v Button, 371 US 415, 438 (1963).

${ }^{27}$ See United States v Petrillo, 332 US 1, 7-8 (1947). 
scribed to citizens and guidance to courts. ${ }^{78}$ Given these concerns, courts should ask two questions when evaluating vagueness challenges to telephone harassment statutes: first, is the vagueness avoidable; and second, in light of the narrowing elements of the statute, does the vagueness in the terminology pose serious due process concerns? If the answer to both questions is "no," there is no constitutional vagueness problem. Even if the vagueness is avoidable, there is no constitutional reason to invalidate the statute; courts should simply construe such statutes narrowly to clarify this vagueness. Only if the statute, when narrowly construed, still poses a serious possibility of confusion should the statute be voided for vagueness.

The inherently vague nature of the terminology used in telephone harassment statutes has caused problems as the courts have attempted to draw fine distinctions between terms as similar as "harass" and "annoy," or "obscene" and "profane."" With the first two terms, the imprecision can be avoided. The latter two terms are more problematic.

Terms like "harass" and "annoy" are used in telephone harassment statutes to describe the intent of the caller. They are meant to ensure that only calls made for the purpose of causing discomfort or distress to their recipients are prohibited. Thus, though the terms are frequently challenged as vague and overbroad because they may be interpreted to reach constitutionallyprotected expression, both vagueness and overbreadth problems can be avoided if the two terms are defined to encompass only "behavior intended to cause psychic or emotional distress to the recipient of the call." ${ }^{\text {80 }}$

${ }^{78}$ See People v Taravella, 313 Mich App 515, 350 NW2d 780, 784 (1984); Bachowski $v$ Salamone, 39 Wis 2d 397, 407 NW2d 533, 537 (1987).

79 See note 25.

so The Model Penal Code $\S 250.4$ (1) (cited in note 72) provides: "a person commits [harassment when], with purpose to harass another, he ... makes a telephone call without purpose of legitimate communication." The drafters believed that in terms of statutory precision "it is probably impossible to do any better." MPC $\$ 250.4(1)$, comment at 371 . This conclusion is dubious. First, the term "harass" can be narrowed to provide greater administrability while at the same time satisfying both the vagueness and overbreadth doctrines. When a statute, or portion thereof, is limited to speech having "no legitimate purpose," it cannot be applied to calls during which the caller even momentarily possessed a legitimate intent. But it is not unconstitutional to punish a caller for the harassing portion of a call which also contained legitimate conversation, so long as the effect of punishing such calls is not to chill protected speech. By defining the operative term "harass" to encompass only intentional inflictions of psychic or emotional distress, it should be clear that when a caller had the "intent to harass" he did not intend "legitimate" communication. Second, the clause "without purpose of legitimate communication" does little to clarify the statute. 
Unlike terms describing intent, terms used to describe the offensive content of harassing telephone calls cannot be easily defined to avoid indefiniteness. Arguments about whether "obscene" is more definite than "profane," or "lewd" more lucid than "lascivious," are purely academic. As a practical matter all such terms are vague, perhaps unavoidably so. Attempts to define these terms narrowly are therefore futile. ${ }^{81}$

Although courts sometimes define obscenity narrowly in other contexts to protect the due process rights of potential offenders, ${ }^{82}$ as argued above, ${ }^{83}$ statutory obscenity and obscene language as an element of telephone harassment are quite distinct. Telephone harassment statutes punish people for intentionally and maliciously invading individual privacy, not for mouthing obscenities. A caller who uses obscene language during a call which he initiated, but not for the intended purpose of harassing the recipient, would not be culpable under this Comment's definition, regardless of the subjective effect on the listener. Because the caller's obscene or offensive speech only colors what is in itself a prohibitable act, the due process concerns surrounding the specificity of the relevant terminology are minimized, making some degree of statutory vagueness permissible.

\section{A Model Statute}

This final section proposes a model telephone harassment statute that criminalizes only telephone calls in which the caller subjects the recipient to an intolerable intrusion of substantial privacy interests. This formulation attempts to reconcile the constitutional theory underlying state restriction of harassing telephone calls with the application of the law in specific cases. Because the state's

\footnotetext{
"Such a 'limiting construction' disguises the constitutional difficulties of the statute but does nothing to resolve them. A judge or a jury still has to determine whether the particular speech of the defendant was 'for a legitimate purpose." "Bolles v People, 189 Colo 394, 541 P2d 80, 83 (1975) (en banc). Rather than requiring "no legitimate purpose," a statute could more properly create a residual offense that would forbid all calls made with the sole and exclusive purpose to harass. The effect of such a provision is the same, but this formulation avoids the vagueness inherent in defining an offense in terms of the legitimacy of the speech.

${ }^{81}$ See Ray, 733 P2d at 28-29. Also see model statute proposed in Comment, A Remedial Approach to Harassment, 70 Va L Rev 507, 527-28 (1984).

s2 See Chaplinsky v New Hampshire, 315 US 568, 571-72 (1942) (defining "obscenity" as part of a class of utterances which "are of such slight social value as a step to truth that any benefit that may be derived from them is clearly outweighed by the social interest in order and morality").

${ }^{83}$ See text at notes $46-49$.
} 
authority to regulate in this area derives from the interest in protecting individuals who are unable to avoid intrusions on their personal, residential privacy, the statute provides a mechanism for limiting regulation in intimate relational settings where diminished privacy interests may not warrant government intervention. Furthermore, the statute recognizes that limits placed on state regulation by the First Amendment are inapposite where the citizen, not the government, is the agent acting to suppress certain communications. On this basis, the statute provides a self-executable "notice remedy" to citizens who desire not to receive further communications from a particular caller.

\section{A. Proposed Model Statute}

The proposed statute provides:

(1) It shall be unlawful for a person:

(a) To make a telephone call with the sole intent to harass the recipient of the call; or

(b) To make a telephone call, with the intent to harass the recipient of the call, without disclosing one's identity; or

(c) To make a telephone call to a non-consenting recipient, with the intent to harass, using obscene language; or (d) To make repeated telephone calls to a non-consenting recipient, with the intent to harass, during which conversation ensues; or

(e) To make a telephone call when the recipient of the call or other person at the called number has previously instructed the caller not to call again.

(2) Definitions:

(a) This statute applies only to unsolicited calls made to persons at their private residences or other similar locations where they would reasonably expect a substantial degree of privacy;

(b) Under subsections (1)(c) and (d) the "intent to harass" required by the statute must exist at the time the call was initiated;

(c) The phrase "intent to harass" encompasses any behavior intended to cause psychic or emotional distress to the recipient of the call;

(d) The phrase "sole intent to harass" means (i) that the call must have been made with the exclusive purpose of 
harassment, and (ii) that this purpose must have remained exclusive for the duration of the call;

(e) The phrase "make a telephone call" means to intentionally dial the phone and allow the telephone to ring, and includes (i) instances where the caller requests a return call from the recipient and upon receipt of the return call commences to engage in behavior prohibited by the statute, (ii) operator-assisted calls, and (iii) calls made by mechanical, electronic, or computer devices under human control;

(f) The term "non-consenting recipient" does not include those persons involved in intimate personal relationships with the caller, unless it may be shown that under the circumstances prevailing at the time the call was initiated the caller could not have reasonably believed that the recipient would consent to the manner of the call or the language used. "Intimate personal relationships" includes relationships between spouses, unmarried cohabitants, and intimate friends or relatives;

(g) The term "repeated telephone calls" means more than one call in close enough proximity to rightly be termed a single episode. Under subsection $(1)(d)$ of the statute the calls need not be made to the same recipient.

\section{B. Application and Evaluation}

The proposed statute operates within the parameters of the Cohen "intolerability" standard, which can define the substantive limits placed on telephone harassment regulation by the First Amendment. The following analysis shows that the proposed statute does not exceed these constitutional limits, and offers a method that courts recognizing the intolerability standard can follow in adjudicating overbreadth and vagueness challenges.

1. Subsection (1)(a): Calls made with the sole intent to harass.

This subsection of the statute is aimed at calls made with no legitimate purpose whatsoever. Telephone calls made with the sole intent to harass merit no constitutional protection when "harass" is defined, as here, to mean "behavior which causes psychic or emotional distress to the recipient of the call." Because there is no intent to communicate ideas between persons, the First Amendment simply does not apply. 
Under subsection (1)(a) it is not enough that the caller possessed the intent to harass when he initiated the call. As defined in subsection (2)(d), "sole intent" means: first, that the call must have been made with the exclusive purpose of harassment; and second, that purpose must have persisted for the duration of the call. The apparent difficulty of proving "sole intent" will serve to constrain prosecutions under this subsection. Where "sole intent" may be shown, however, this subsection prohibits calls that might otherwise fall within another subsection of the statute because of anonymity, obscenity, or repetition. Unlike subsections (1)(c) and (d), this subsection extends no particularized protection to callers in cases of intimate relationships. However, prosecution under this subsection seems unlikely where the caller and the recipient have a prior relationship that renders more plausible a supposed legitimate purpose in calling. ${ }^{84}$ Finally, note that subsection (1)(a), when read in conjunction with subsection $(2)(\mathrm{e})$-which states that the act of making a telephone call is complete once the number is dialed and the phone is allowed to ring-may be violated regardless of whether the caller speaks, or even whether the recipient answers.

\section{Subsection (1)(b): Anonymous calls.}

This subsection of the statute focuses specifically on intentionally harassing anonymous calls. The courts generally agree that anonymous calls do not merit much First Amendment protection from state restriction. ${ }^{85}$ Read in conjunction with subsection (2)(e), the statute prohibits anonymous calls even where no actual conversation ensues, the telephone is allowed to ring continuously unan-

84 A similar observation has been made regarding a section of the federal telephone harassment statute, 47 USC $\$ 223(a)(1)(D)$ (cited in note 2), which provides: "[it shall be unlawful] by means of telephone [to] make[] repeated telephone calls, during which conversation ensues, solely to harass any person at the called number." (Emphasis added). In United States v Darsey, 342 F Supp 311, 313-14 (E D Pa 1972), the court noted: "[M]any situations, and most especially in romantic and family conflicts, ... are and should be below the cognizance of the law. This Court does not read this section of the law to extend to these situations, no matter how much sympathy it might have for one side or the other in such a conflict, unless some completely unjustifiable motive, such as revenge or cruelty, motivates such repeated contacts . . between those known to each other. Only then can such calls be properly called 'solely to harass." (Emphasis added).

${ }^{85}$ See note 18 . While most anonymous calls have no redeeming value, an anonymous call may contain entirely legitimate communications. Consider the example of a "whistleblower" who anonymously reports information to a government official or the media. Nonetheless, where anonymity is combined with intent to harass, such calls are intolerable. 
swered, or a call is placed and the caller deliberately refuses to hang up.

Note that, unlike subsections (1)(c) and (d), the culpable intent here need not be the motivating purpose of the call. This subsection only requires that the caller possess the intent to harass at some point during the call. We are not, after all, bothered by the prospect of a chilling effect on paradigm anonymous telephone calls-"virtually any willfully bad motive in making an anonymous phone call should be punishable."

3. Subsection (1)(c): Calls involving the use of obscene language.

This subsection prohibits the use of obscene language in intentionally harassing calls where the recipient does not actually or implicitly consent to the manner of the call or to the language used. The term "obscene" is not defined by the statute, but should be understood as joining the common meaning of the term ${ }^{87}$ with the statute's definition of the term "harass"--"behavior which causes psychic or emotional distress to the recipient of the call."

The bar on intentionally harassing obscene calls is limited by subsection (2)(f), which in effect creates a presumption that persons involved in intimate personal relationships with the caller are consenting recipients. The presumption fails, however, if it is shown that at the time the call was placed, circumstances prevailed which would have made it unreasonable for the caller to have believed the recipient would consent to the manner of the call or the language used. ${ }^{88}$ At first glance, the application of such a presumption to obscene calls may appear extreme, but in fact it is a reasonable accommodation of the diminished privacy interests encountered in intimate relationships. ${ }^{89}$

so Darsey, 342 F Supp at 313.

${ }^{87}$ For instance, Webster's Dictionary defines "obscene" as "grossly repugnant to the generally accepted notions of what is appropriate." Webster's Third World Dictionary (unabridged) at 1557 (cited in note 25).

${ }^{88}$ Under this section of the statute, recipients are presumed to be unwilling unless the caller can persuade the court that an intimate relationship exists. Once this burden of persuasion is met, the recipient will then be presumed to have consented to the call unless he can defeat the presumption of consent. This would be done by (1) proving that there was in fact no such relationship, or (2) proving that the circumstances surrounding the relationship were not such that the caller could have reasonably believed that the recipient would consent to the call.

${ }^{80}$ The proposed statute may be subject to criticism for being overprotective of intentionally harassing callers because it does not prohibit single calls made with intent to harass where no other aggravating factors exist. This is the result of a conscious decision not to 
The intimate-relationship exception applies only to subsections (1)(c) and (d); other types of calls are considered so intolerable that no prior relationship would eradicate the recipient's privacy expectations. The exception is strictly circumscribed. It applies only to isolated calls between intimates and even then only under circumstances where it would be reasonable for the caller to presume consent by the recipient. This exception, of course, may be defeated at any time by the recipient's communication to the caller that such calls are not welcome. ${ }^{90}$

Calls involving the caller's use of obscene language thus present a difficult case under the intolerability analysis. In subsections (1)(a) and (b), it is not necessary to consider the nature of the privacy interests in order to justify state restriction because the total absence of communicative intent (i.e., where "sole intent" is required) or the implied absence of communicative substance (i.e., prohibiting intentionally harassing anonymous calls) are enough to render such calls intolerable. In relation to calls involving obscene language, however, the level of intolerability may vary considerably depending on the relationship between the caller and the recipient. Although some courts, including the Supreme Court, have assumed that all forms of obscenity are "no essential part of any exposition of ideas, and are of such slight social value as a step to truth that any benefit that may be derived from them is clearly outweighed by the social interest in order and morality," the state may "not proscribe obscene telephone communications regardless of the circumstances." ity is uttered must be taken into account in determining what is "intolerable," because the term "obscenity" evades precise definition. ${ }^{93}$ Indeed, "nowadays, obscene, lewd or profane language is not uncommonly used between individuals without any intent to terrify, intimidate, threaten, harass, annoy, or offend." "94 Even in the context of intentionally harassing telephone calls, it is not clear that the use of obscene language makes such calls intolerable in all circumstances.

Subsection (2)(f) by no means immunizes from prosecution all

unduly restrict robust conversation by telephone. Allowing a one-call "free shot" is by no means extraordinary. See note 72.

${ }^{\text {so }}$ See discussion of subsection (1)(e) below.

91 Chaplinsky, 315 US at 572. See also Cohen, 403 US at 24-25.

${ }^{92}$ Keaton, $371 \mathrm{~S} 2 \mathrm{~d}$ at 92.

${ }^{93}$ See Jacobellis v Ohio, 378 US 184, 187 (1964) (a "dim and uncertain" line separates obscenity from constitutionally protected expression).

2 Baker, 494 P2d at 72. 
intentionally harassing calls made between intimate persons. ${ }^{95}$ The recipient may defeat the presumption of consent by proving that the caller's presumption was objectively unreasonable. In addition, even where this burden is not or cannot be met, the recipient may seek remedy through other sections of the statute. Finally, the recipient himself may terminate the presumption created by the relationship by so notifying the caller. When considered in conjunction with these other remedies, the intimate-relationship exception to subsection $(1)(c)$ serves only to protect open and uninhibited communication.

The very essence of obscenity revolves around issues of privacy. To the extent that obscenity is subject to restriction, it is because it forces upon the public consciousness ideas, thoughts, or images that are considered purely for private consumption..$^{96}$ Where words conjuring up such thoroughly private ideas are conveyed between persons who share intimate privacy, the government's interest is less compelling given the pervasive chilling effect that regulation of such calls would create. ${ }^{97}$

Obscene language used in harassing telephone calls is not per se unprotected under the proposed statute. Obscenity may be used in harassing calls to assault the recipient in an indecent and intolerable manner: such behavior is unprotected. Language falling under the broad rubric of obscenity may, however, be used between intimates as a way of expressing anger, frustration, or even more benign sentiments. Such calls made between intimates are not easily classified as "unreasonable conduct which, by its very nature, erodes the peace of mind and solitude of an unsuspecting individual,"9s and a statute reaching these cases would be overbroad. ${ }^{\text {99 }}$

9s The intimate relationship exception actually provides greater protection for recipients than do existing laws. Under prevailing statutory frameworks, callers are given substantial protection through prosecutorial discretion. Where an intimate relationship exists, the chances that criminal action will be initiated are slight. The proposed statute, by codifying the limits on prosecuting callers in such relationships, largely removes the issue of prosecutorial discretion.

${ }^{28}$ See Pacifica, 438 US at 746 n 23.

92 "[T] offensive sexual and excretory language need not be the same in every context." Id at 729.

${ }^{28}$ State $v$ Crelly, 313 NW2d 455, 457 (SD 1981).

9 Consider, for instance, State $v$ Keaton, 371 S2d 86 (Fla 1979), where a section of the Florida statute (Fla Stat $\$ 365.16$ (1977)), patterned after the federal statute, was found unconstitutionally overbroad. The court in Keaton found that "[j]ust as the first amendment freedom of speech protects the right of an individual to possess obscene material in his home [see Stanley $v$ Georgia, 394 US 557 (1969)], this freedom also prohibits the punishment of the mere use of obscene language in a telephone communication." 371 S2d at 91 . As 
Some statutes are framed broadly, treating all obscene language as unprotected, leaving the courts to construe the statute so as not to reach these cases. ${ }^{100}$ Other statutes are framed more narrowly, requiring specific intent and narrowly defining the scope of obscenity covered by the statute. ${ }^{101}$ The proposed statute takes an intermediate approach. Under this statute, obscene language is merely an aggravating factor in a harassing call. While the statute does not prohibit single calls made with intent to harass, an exception is made if obscene language is used in a call to a "non-consenting recipient."

\section{Subsection (1)(d): Repeated calls.}

This subsection is directed at non-obscene, non-anonymous repeated harassing calls. The caller need not use harassing speech at all; it is enough that he initiated successive calls with the intent to harass. Prohibitions of this sort, if not narrowly limited, could reach protected communications. To avoid potential overbreadth, this subsection, when read in conjunction with subsection (2)(b), requires that the intent to harass be the purpose initially motivating the call. ${ }^{102}$

the court also noted, it is "the privacy interests of the listener [] which constitutionally entitle the state to protect him from unwilling subjection to verbal abuse." Id at 92 . Thus, in cases of intimate relationships, where the recipient's privacy interests vis-à-vis the caller are reduced, the State's regulatory interest is less compelling.

100 The federal statute, 47 USC $\S 223(a)(1)(A)$, making it a criminal offense to "by means of telephone ... make any comment, request, suggestion or proposal which is obscene, lewd, lascivious, filthy or indecent," fits this description-it "was drawn broadly to prevent technical escape by the guilty." Darsey, 342 F Supp at 312. This section of the statute is identical to the section found overbroad in Keaton, 371 S2d 86 . Both statutes seem clearly overbroad. They contain no specific intent requirement. Any call containing such a comment or suggestion, regardless of whether legitimate communication was intended or conveyed, would be subject to prosecution. Nor is the statute limited in its application to intimate relationships. Nevertheless, the federal statute was upheld in Darsey, where the court interpreted subsection (A), in light of its legislative history, as not intended "to make criminal the use of ungenteel or vulgar language sometimes called 'obscene' in the course of an interstate telephone conversation, either from habit, anger or slanderous intent." $342 \mathrm{~F}$ Supp at 312. The court in Darsey also interpreted the statute as not reaching "romantic and family conflicts," which the court believed were "below the cognizance of the law." Id at 314.

101 See note 81.

${ }^{102}$ To violate this subsection the offender must engage in conversation. But subsection (2)(e) defines the phrase "make a telephone call" to include operator-assisted calls. This suggests that in such instances the operator becomes a constructive agent for the caller. Thus, the subsection may be violated even where the caller utters no words so long as the operator engages in some form of communication with the person receiving the call. See Lampley, 573 F2d at 787-88, where this issue was litigated. As discussed above, sole intent to harass is an aggravating factor which virtually eliminates the overbreadth concern. 
The repetition of harassing calls is an aggravating factor that makes such calls more intolerable. Prudence may justify a handsoff policy for single calls made with the intent to harass, but as harassing calls are repeated the state interest in intervening to protect the recipient becomes more compelling. Citizens should not be left without remedy when a caller engages in a series of harassing calls. This subsection also recognizes that the repetition itself, without other aggravating factors, is not so intolerable as to overcome potential overbreadth problems inherent in application to intimate persons. ${ }^{103}$ If harassing, but unaggravated, calls made between intimate persons are not normally subject to regulation, it is not clear that such calls should be any more subject to regulation when repeated. If the caller has a reasonable belief that the recipient will consent to the manner and content of his communication, there should be no limit to the number of calls he can make. Of course, where the recipient demonstrates his displeasure or disgust in the previous call, the caller's belief that the recipient will consent to subsequent calls of a similar nature becomes less convincing.

\section{Subsection (1)(e): Calls repeated after notice.}

This subsection prohibits repeated calls, regardless of intent, where the caller has previously been instructed not to call again. It arms recipients with a self-executable "notice remedy." Anyone who upon receiving a harassing call-or for that matter, any call-decides he does not want to receive a subsequent call from that particular caller may instruct the caller not to call again, after which any subsequent call would be prohibited.

The justification for subsection (1)(e) follows from the substantiality of the privacy interests placed at issue when a recipient unequivocally states a desire not to receive further calls. As discussed above, the Supreme Court in Rowan recognized the right of citizens to protect themselves from unwanted communications into the household by erecting privacy barriers that cannot legally be penetrated without the householder's acquiescence. ${ }^{104}$ Thus, where a citizen gives notice to someone who desires to communicate an unwanted message by telephone, the privacy interests of the citizen vis-à-vis the particular caller are at their highest. Because a

${ }^{103}$ See 47 USC $\S 223(a)(1)(D)$, in which Congress required the caller to have a sole intent to harass in repeated calls where conversation ensues. As discussed above, sole intent to harass is an aggravating factor which virtually eliminates the overbreadth concern.

104 See discussion of Rowan in text at notes 73-75. 
caller has no constitutional right to communicate by phone to the prior recipient after having received such an instruction, offenses under this subsection of the statute do not require any form of specific intent.

\section{ConcLusion}

Restricting telephone harassment is an especially difficult legislative undertaking. The conscientious legislator is caught in a whirlwind of competing rights and immunities. The legislator rightly hesitates before proscribing a citizen's expression-a liberty essential to the free flow of ideas and the stability of relationships in our society. But he is nevertheless compelled to protect the right of the same citizens peacefully to enjoy the solemn confines of their private dwellings. The legislator thus reaches a compromise-he will forbid only those intrusions that, because of hostile intent or offensive content, cannot be thought to further societal interests. He knows that if he strikes an improper balance between speech and privacy those more astute in the law will correct his error. In time the courts do speak, but their message is brief: "Void-try again."

This Comment attempts to ease the legislative task of drafting telephone harassment regulation. It suggests a way in which both courts and legislatures can look at the constitutional issues raised by such regulation, and it proposes a statute corresponding with this view. The unique benefit of the proposed statute is that it attempts to codify speech and due process protections that the prevailing system provides, if at all, only through judicial construction or prosecutorial discretion. Short of legislatures adopting statutes similar to those proposed here, the law regarding telephone harassment will only become clearer if courts reach beyond the narrow confines of conventional overbreadth and vagueness review to articulate the substantive limits of telephone harassment regulation. As it now stands, the uncertainty in this area of the law has the effect of chilling legislative experimentation. Just as courts are reluctant to break from the narrow pattern of conventional overbreadth and vagueness review, legislatures fearing the unknown hesitate to depart from the typical, but inadequate, statutory formulation. 